\title{
Deafness, Autosomal Recessive 28
}

National Cancer Institute

\section{Source}

National Cancer Institute. Deafness, Autosomal Recessive 28. NCI Thesaurus. Code C129023.

An autosomal recessive disorder caused by mutations in the TRIOBP gene, encoding TRIO and F-actin-binding protein. The condition is characterized by severe to profound sensorineural hearing loss. 